\title{
Pengaruh Perkembangan Usaha Mikro, Kecil, dan Menengah Terhadap Pendapatan Nasional Pada Sektor UMKM di Indonesia
}

${ }^{1}$ Lies Maria Hamzah, Fakultas Ekonomi dan Bisnis (FEB) Universitas Lampung (Unila), Indonesia

${ }^{2}$ Devi Agustien, Fakultas Ekonomi dan Bisnis (FEB) Universitas Lampung (Unila), Indonesia

\section{Informasi Naskah}

Submitted: 27 Juni 2019

Revision: 13 Juli 2019

Accepted: 28 Juli 2019

Kata Kunci:

$P D B$ UMKM, investasi UMKM, tenaga UMKM, jumlah unit UMKM

\begin{abstract}
This study aims to analyze the influence of the development of Micro, Small, and Medium Enterprises on the national income of the UMKM sector in Indonesia. This research used a panel data method with Fixed Effect Model. The data used are secondary in the value of GDP of UMKM, Labours of UMKM, investment of UMKM, and the number of units of UMKM from the 2000-2013 period. The results showed that labors of UMKM and placement of UMKM have a positive and significant effect on the national income of the UMKM sector in Indonesia. While for the number of units of UMKM not affect the national income of the UMKM sector in Indonesia.
\end{abstract}




\section{PENDAHULUAN}

Krisis moneter dan ekonomi yang melanda Indonesia meng-akibat lemahnya perekonomian nasional. Krisis ekonomi yang terjadi di negara kita, dimana banyak usaha berskala besar yang mengalami stagnasi bahkan berhenti aktifitasnya, dan sektor Usaha Mikro, Kecil, dan Menengah (UMKM) lebih tangguh dalam menghadapi krisis tersebut. Sektor usaha mikro kecil menengah mempunyai daya tahan yang tinggi sehingga mampu bertahan dari krisis ekonomi dan moneter. UMKM mempunyai peran yang strategis dalam perekonomian nasional, oleh karena selain berperan dalam perekomian nasional dan penyerapan tenaga kerja juga berperan dalam pendistribusian hasil- hasil pembangunan.

Oleh karena itu UMKM dapat diperhitungkan dalam meningkat-kan kekompetitifan pasar dan stabilitasi sistem ekonomi yang ada (Kementrian Koperasi dan UMKM, 2008).

Pasca krisis ekonomi tahun1997-1998 jumlah UMKM tidak berkurang, justru meningkat terus, bahkan mampu menyerap 85 juta hingga 107 juta tenaga kerja sampai tahun 2012. Pada tahun 2012, jumlah pengusaha di Indonesia sebanyak 56.539 .560 unit. Dari jumlah tersebut, Usaha Mikro Kecil dan Menengah (UMKM) sebanyak 56.534.591 unit atau 99.99\%. Sisanya, sekitar $0,01 \%$ atau 4.968 unit adalah usaha besar. Data tersebut membuktikan, UMKM merupakan pasar yang sangat potensial bagi industri jasa keuangan, terutama bank untuk menyalurkan pembiayaan. Karena sekitar 60-70\% pelaku UMKM belum memiliki akses pembiayaan perbankan (Bank Indonesia, 2015).

Peran UMKM dalam perekono-mian Indonesia ditunjukkan oleh peranannya sebagai pelaku usaha terbesar, serta kontribusinya dalam penyerapan tenaga kerja, pem-bentukan produk domestik bruto (PDB), ekspor dan penciptaan modal tetap/investasi (Kementrian Koperasi dan UMKM, 2015). UMKM memiliki potensi yang begitu besar namun kenyataanya UMKM masih mengalami masalah yang hingga kini masih menjadi kendala adalah keterbatasan modal yang dimiliki dan sulitnya UMKM mengakses sumber permodalan.

Perkembangan UMKM dalam perekonomian Indonesia ditunjukkan oleh populasinya sebagai pelaku usaha terbesar, serta kontribusinya dalam penyerapan tenaga kerja, pembentukkan produk domestik bruto (PDB), ekspor, dan penciptaan modal tetap atau investasi (Tabel 1).

Tabel 1 menunjukkan bahwa perkembangan UMKM di Indonesia yang dilihat dari kinerja UMKM secara umum cukup bervariasi dari tahun ke tahun. Kontribusi PDB UMKM berfluktuasi, kondisi ini diakibatkan tingkat pertumbuhan output UMKM yang cenderung berfluktuasi dan masih lebih rendah dibandingkan output usaha besar. Dampak dari kondisi ini yaitu adanya kesenjangan tingkat produktivitas antara UMKM dan dan usaha besar.

Tabel 2 menunjukkan bahwa tingkat produktivitas UMKM di Indonesia selama kurun waktu 2010 - 2013 yang dilihat dari jumlah unit usaha dan jumlah tenaga kerja cenderung mengalami kenaikan, namun tren yang terjadi dalam jumlah unit usaha cenderung berfluktuasi. Secara keseluruhan UMKM cenderung menurun dari tahun 2010-2013 sebesar 2 persen. Sedangkan produktivitas jumlah tenaga kerja UMKM mengalami rata-rata kenaikan pada tahun 2010-201 sebesar 6 persen, berbeda dengan produktivitas tenaga kerja yang terjadi di usaha besar yang cenderung mengalami kenaikan tahun 2010-2013 rata-rata sebesar 8 persen.

Tabel 1.

Data Indikator Perkembangan UMKM Tahun 2010 - 2013

\begin{tabular}{|c|c|c|c|c|c|}
\hline INDIKATOR & Satuan & 2010 & 2011 & 2012 & 2013 \\
\hline $\begin{array}{l}\text { Jumlah Unit } \\
\text { Usaha }\end{array}$ & Unit & 54.114 .821 & 55.206 .444 & 56.534 .591 & 57.895 .721 \\
\hline Perkembangan & & $3 \%$ & $2 \%$ & $2 \%$ & $2 \%$ \\
\hline $\begin{array}{l}\text { Tenaga Kerja } \\
\text { Perkembangan }\end{array}$ & Orang & $\begin{array}{c}98.238 .913 \\
2 \%\end{array}$ & $\begin{array}{c}101.722 .458 \\
4 \%\end{array}$ & $\begin{array}{c}107.657 .509 \\
6 \%\end{array}$ & $\begin{array}{c}114.144 .082 \\
6 \%\end{array}$ \\
\hline $\begin{array}{l}\text { PDB (Harga } \\
\text { Konstan } \\
\text { Th.2000) }\end{array}$ & $\begin{array}{l}\text { Miliar } \\
\text { Rupiah }\end{array}$ & $1.282 .571,8$ & 1.369 .326 & $1.451 .460,2$ & $1.535 .502,4$ \\
\hline $\begin{array}{l}\text { Perkembangan } \\
\text { Ekspor Non }\end{array}$ & Juta & $\begin{array}{c}6 \% \\
175.894 .895\end{array}$ & $\begin{array}{c}7 \% \\
187.441 .824\end{array}$ & $\begin{array}{c}6 \% \\
166.626 .455\end{array}$ & $\begin{array}{c}6 \% \\
182.112 .745\end{array}$ \\
\hline
\end{tabular}




\begin{tabular}{|c|c|c|c|c|c|}
\hline $\begin{array}{l}\text { migas } \\
\text { Perkembangan }\end{array}$ & Rupiah & $8 \%$ & $7 \%$ & $-11 \%$ & $9 \%$ \\
\hline $\begin{array}{l}\text { Investasi } \\
\text { (Harga } \\
\text { Konstan } \\
\text { Th.2000) }\end{array}$ & $\begin{array}{l}\text { Juta } \\
\text { Rupiah }\end{array}$ & 247.139 .455 & 260.934 .760 & 300.175 .675 & 341.341 .591 \\
\hline Perkembangan & & $10 \%$ & $6 \%$ & $15 \%$ & $14 \%$ \\
\hline
\end{tabular}

Sumber: BPS dan Kementerian Koperasi dan UKM (2010-2013 diolah)

Tabel 2.

Produktivitas Pelaku Usaha Berdasarkan Unit dan Tenaga Kerja Tahun 2010-2013

\begin{tabular}{|c|c|c|c|c|c|c|c|c|}
\hline \multirow{3}{*}{ Skala } & \multicolumn{2}{|c|}{2010} & \multicolumn{2}{|c|}{2011} & \multicolumn{2}{|c|}{2012} & \multicolumn{2}{|c|}{2013} \\
\hline & Per- & Per- & Per- & Per- & Per- & Per- & Per- & Per- \\
\hline & Unit & Tenaga Kerja & Unit & Tenaga Kerja & Unit & Tenaga Kerja & Unit & Tenaga Kerja \\
\hline $\begin{array}{l}\text { Usaha } \\
\text { Mikro }\end{array}$ & 53.504 .416 & 91.729 .384 & 54.559 .969 & 94.957 .797 & 55.856 .176 & 99.859 .517 & 57.189 .393 & 104.624 .466 \\
\hline $\begin{array}{l}\text { Usaha } \\
\text { Kecil }\end{array}$ & 568.397 & 3.768 .885 & 602.195 & 3.919 .992 & 629.418 & 4.535 .970 & 654.222 & 5.570 .231 \\
\hline $\begin{array}{l}\text { Usaha } \\
\text { Menengah }\end{array}$ & 42.008 & 2.740 .644 & 44.280 & 2.844 .669 & 48.997 & 3.262 .023 & 52.106 & 3.949 .385 \\
\hline $\begin{array}{l}\text { UMKM } \\
\text { Usaha }\end{array}$ & 54.114 .821 & 98.238 .913 & 55.206 .444 & 101.722 .45 & 56.534 .591 & 107.657 .509 & 57.895 .721 & 114.144 .082 \\
\hline Besar & 5.150 & 2.753 .049 & 4.952 & 2.891.224 & 4.968 & 3.150 .645 & 5.066 & 3.537 .162 \\
\hline Total & 54.119 .971 & 100.991 .962 & 55.211 .396 & $\begin{array}{c}104.613 .68 \\
1\end{array}$ & 56.539 .559 & 110.808 .154 & 57.900 .787 & 117.681 .244 \\
\hline
\end{tabular}

Sumber: BPS dan Kementerian Koperasi dan UKM (2010-2013 diolah)

UMKM memiliki daya tahan yang lebih baik terhadap krisis terlepas dari produktivitas yang rendah. Hal ini dikarenakan struktur organisasi dan tenaga kerja UMKM yang lebih fleksibel dalam menyesuaikan dengan perubahan pasar. Daya tahan dan fleksibilitas ini menjadikan UMKM digunakan oleh sebagian besar masyarakat sebagai sumber utama penghidupan.

Berdasarkan tingkat produktivitas dan kebutuhan untuk meningkatkan populasi UMKM, maka pengem-bangan UMKM dalam meningkatkan produktivitas usaha mikro harus lebih mendapat perhatian. Pening-katan kapasitas usaha mikro diharapkan dapat: meningkatan pendapatan masyarakat dan mengurangi kemiskinan.

Memperkuat basis produksi dalam negeri dan partisipasi di pasar ekspor.

Kontribusi masing-masing sektor ekonomi UMKM terhadap PDB porsi terbesar dipegang oleh sektor perdagangan, hotel dan restauran sebesar $27 \%$, selanjutnya pertanian, perternakan, kehutanan, dan perikanan sebesar $21 \%$, sementara jasa- jasa swasta dan keuangan, persewaan, dan jasa perusahaan memiliki kontribusi yang sama.

Perkembangan PDB UMKM dipengaruhi oleh beberapa variabel yang digunakan untuk mengukur perkembangan UMKM diantaranya yaitu: tenaga kerja, investasi dan unit usaha. Penelitian ini ingin melihat perkembangan dari tenaga kerja UMKM, investasi UMKM, dan jumlah unit UMKM terhadap pendapatan nasional UMKM dari tahun 2000-2013, yang ditinjau dari tiga sektor ekonomi dengan kontribusi terbesar.

Kinerja perekonomian dari suatu negara dalam periode tertentu dapat diukur melalui satu indikator penting yaitu pendapatan nasional. Pendapatan nasional mencerminkan terjadinya alokasi yang efisien secara makro yang merupakan nilai output nasional yang dihasilkan oleh sebuah perekonomian pada suatu periode tertentu. Pendapatan Nasional merupakan salah satu tolak ukur yang dapat digunakan untuk menilai kondisi perekonomian suatu negara. Tujuan dari perhitungan pendapatan nasional ini adalah untuk mendapatkan gambaran tentang tingkat ekonomi yang telah dicapai dan nilai output yang diproduksi, komposisi pembelanjaan agregat, sumbangan dari berbagai sektor perekonomian, serta tingkat kemakmuran yang dicapai (Sukirno, 2008).

Produk Domestik Bruto (PDB) adalah nilai pasar seluruh barang dan jasa akhir yang diproduksi disuatu negara pada periode tertentu. Produk domestik bruto sering dianggap sebagai ukuran terbaik dari kinerja perekonomian (Mankiw, 2013). Produk domestik bruto merupakan salah satu ukuran atau indikator yang secara luas digunakan untuk mengukur kinerja 
ekonomi atau kegiatan makroekonomi suatu negara (Nanga, 2001).

Badan Pusat Statistik (BPS) mendefinisikan UMKM berdasarkan kuantitas tenaga kerja. Usaha kecil merupakan entitas usaha yang memiliki jumlah tenaga kerja 5 s.d 19 orang, sedangkan usaha menengah merupakan entitias usaha yang memiliki tenaga kerja 20 s.d.99 orang. adalah;

Menurut UU No 20 Tahun 2008 tentang Usaha Mikro, Kecil, dan Menengah (UMKM)

1. Usaha Mikro, yaitu usaha produktif milik orang per-orangan atau badan usaha milik perorangan yang memenuhi kriteria yakni :

a. Memiliki kekayaan bersih paling banyak Rp 50.000 .000 (lima puluh juta rupiah) tidak termasuk tanah dan bangunan tempat usaha

b. Memiliki hasil penjualan tahunan paling banyak Rp 300.000 .000 (tiga ratus juta rupiah)

2. Usaha Kecil, yaitu usaha ekonomi produktif yang berdiri sendiri yang dilakukan oleh orang perorangan atau badan usaha yang bukan merupakan anak perusahaan atau bukan cabang perusahaan yang dimiliki, dikuasai atau menjadi bagian baik langsung maupun tidak langsung dari usaha menengah atau usaha besar dengan kriteria tertentu.

3. Usaha Menengah, yaitu usaha ekonomi produktif yang berdiri sendiri, yang dilakukan oleh orang perorangan atau badan usaha yang bukan merupakan anak perusahaan atau cabang perusahaan yang dimiliki, dikuasai, atau menjadi bagian baik langsung maupun tidak langsung dengan usaha kecil atau usaha besar.

\section{METODOLOGI PENELITIAN}

Jenis data yang digunakan dalam penelitian ini adalah data sekunder yang bersifat kuantitatif. Data sekunder yang digunakan adalah data runtut waktu (time series) dari periode 2000 - 2013 dan data silang (cross section) yang melibatkan tiga sektor ekonomi UMKM, yaitu:

1. sektor Perdagangan, Hotel dan Restoran,

2. Pertanian, Peternakan, Kehutanan dan Perikanan, dan

3. Jasa-jasa swasta yang memiliki kontribusi besar terhadap pendapatan nasional dan sektor ekonomi yang variabel indepen-dennya sebagai indikator perkembangan UMKM terdapat di setiap variabel yang peneliti gunakan.

Sumber data berasal dari Kementrian Koperasi dan UMKM di Indonesia dari tahun 2000 sampai tahun 2013.

Penelitian ini terdiri dari satu variabel terikat dan tiga variabel bebas. Pengukuran faktorfaktor yang mempengaruhi pendapatan nasional akan diukur dengan menggunakan regresi data panel. Untuk memperjelas variabel yang akan dianalisi maka perlu dirumuskan sebagai berikut Batasan atau definisi variabel-variabel yang digunakan dalam penelitian ini adalah sebagai berikut:

1. Pendapatan nasional dalam penelitian ini menggunakan data PDB UMKM Atas dasar harga konstan tahun 2000 UMKM di Indonesia periode tahun 2000- 2013.

2. Dalam hal ini adalah tenaga kerja yang diserap oleh UMKM yang diukur dengan satuan orang.

3. Investasi UMKM adalah penanaman modal pada sektor UMKM. Data diukur dalam satuan juta rupiah

4. Jumlah unit UMKM adalah keseluruhan jumlah unit UMKM dalam satuan unit.

Penelitian ini menggunakan data panel yang merupakan gabungan antara data silang (cross section) yaitu tiga sektor ekonomi UMKM dengan data runtut waktu (time series) tahun 2000-2013. Alat yang digunakan berupa software computer program Eviews 9. Model regresi data panel yang digunakan dengan persamaan sebagai berikut :

$$
Y i, t=\beta 0+\beta 1 T K i, t+\beta 2 I U i, t+\beta 3 J U i, t+\varepsilon i, t
$$




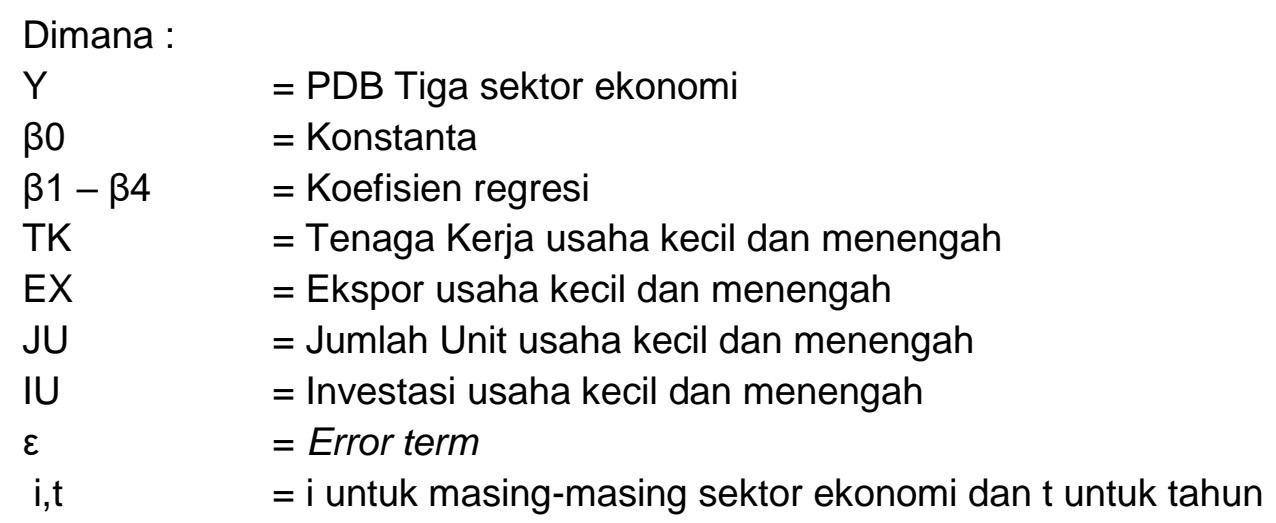

Untuk menentukan teknik mana yang sebaiknya dipilih untuk regresi data panel maka dilakukan tiga pengujian yaitu pertama uji statistik F digunakan untuk memilih antara metode OLS tanpa variabel dummy (common effect) atau fixed effect.Kedua, uji Langrange Multiplier (LM) digunakan untuk memilih antara common effect atau random effect. Ketiga, untuk memilih antara fixed effect atau random effect digunakan uji Hausman. (Widarjono, 2013).

Pengujian Hipotesis digunakan untuk menarik kesimpulan penelitian dan mengetahui keakuratan data dengan melakukan uji-t, uji F dan koefisien determinasi (R2).

\section{HASIL DAN PEMBAHASAN}

\section{Pemilihan Teknik Estimasi Regresi Data Panel}

Pemilihan teknik estimasi regresi data panel dikenal 3 macam pendekatan estimasi yaitu fixed effect, random effect, dan common effect. Untuk menentukan teknik terbaik yang akan digunakan untuk regresi data panel maka dilakukan pengujian yaitu uji chow, uji hausman, dan uji LM.

1. Uji Chow

Uji Chow dilakukan untuk mengetahui model mana yang lebih baik antara common effect dan fixed effect.

Hipotesis pada Uji chow adalah sebagai berikut: Ho : Common Effect

$\mathrm{Ha}$ : Fixed Effect

Kriteria :

Chi-square hitung $<$ Chi-square kritis $=$ Terima Ho

Chi-square hitung $>$ Chi-square kritis $=$ Terima Ha

Berdasarkan Uji Chow yang ditunjukkan pada tabel 6 diperoleh nilai Chi Square Statistic $(72,895106)>$ Chi Square tabel $(5,99)$ pada $\mathrm{df}=2$. Oleh karena itu menolak Ho dan menerima Ha sehingga fixed effect model merupakan model yang tepat untuk digunakan pada regresi data panel.

2. Uji Hausman

Uji Hausman digunakan untuk untuk memilih random effect model dengan fixed effect model dengan syarat tertentu. Nachrowi dan Usman (2006), menyatakan bahwa jika data panel yang dimiliki mempunyai waktu $(\mathrm{T})$ lebih besar dibandingkan dengan jumlah individu $(\mathrm{N})$ maka disarankan untuk menggunakan model fixed effect.

\section{Pengujian Asumsi Klasik}

Pengujian asumsi klasik dilakukan untuk menguji apakah model regresi yang digunakan memenuhi syarat untuk dilanjutkan (Gujarati dan Porter, 2010)

1. Uji Heterokedastisitas

Deteksi heterokedastisitas diguna-kan untuk melihat apakah model regresi memiliki varian yang konstan. Adanya heteroskedas-tisitas dalam model menyebabkan estimator tidak lagi mempunyai varian yang minimum.

Pada tabel ditunjukkan bahwa Chi Square hitung $(6,730164)<$ Chi Square tabel $(7,81)$ 
pada df sebesar variabel bebas $=3$ dan tingkat signifikansi $5 \%$. Hal ini berarti menerima Ha maka tidak terdapat masalah heterokedastisitas dalam persamaan.

2. Uji Autokorelasi

Autokorelasi merupakan adanya korelasi antara anggota observasi satu dengan observasi lain yang berlainan waktu. Untuk mendeteksi apakah terdapat permasalahan autokorelasi maka digunakan metode Breusch- Godfrey. tingkat signifikansi 5\%. Hal ini berarti menerima Ho maka terdapat masalah autokorelasi dalam persamaan. Oleh karena itu perlu dilakukan metode white untuk menghilangkan masalah autokore-lasi dengan mengubah Coef Covariance Methode menjadi White-Cross section dalam panel option sehingga merubah persamaan regresi menjadi terbebas dari masalah autokorelasi (Widarjono, 2013).

3. Hasil Estimasi Regresi Data Panel Model Fixed Effect

Berdasarkan Uji Chow, Uji Hausman, dan Uji LM model Fixed Effect yang lebih tepat untuk digunakan dalam penelitian ini. Tabel 4 menunjukkan hasil perhitungan regresi model Fixed Effect.

Tabel 3.

Variabel Penelitian, Simbol, Satuan Pengukuran, Sumber Data

\begin{tabular}{llll}
\hline Variabel & Simbol & Satuan & Sumber Data \\
\hline Pendapatan nasional & PDB & Miliar Rupiah & Kementrian Koperasi dan UMKM \\
Tenaga Kerja & TK & Orang & Kementrian Koperasi dan UMKM \\
Investasi & IU & Juta Rupiah & Kementrian Koperasi dan UMKM \\
Jumlah Unit Usaha & JU & Unit & Kementrian Koperasi dan UMKM \\
\hline
\end{tabular}

Tabel 4.

Hasil perhitungan Regresi Model Fixed Effect

\begin{tabular}{ccccc}
\hline Variable & Coefficient & Std. Error & t-Statistic & Prob. \\
\hline C & -88434.15 & 21509.89 & -4.111325 & $0.0002^{*}$ \\
TK & 0.007226 & 0.001873 & 3.858157 & $0.0005^{\star}$ \\
INVESTASI & 0.003186 & 0.000773 & 4.120712 & $0.0002^{*}$ \\
JU & 0.004461 & 0.004108 & 1.085938 & 0.2847 \\
\hline
\end{tabular}

Sumber: Data Olah dengan Eviews 9

Ket $:{ }^{*}=$ Sig. pada $\alpha=1 \%$

Berdasarkan hasil perhitungan regresi model Fixed Effect adalah:

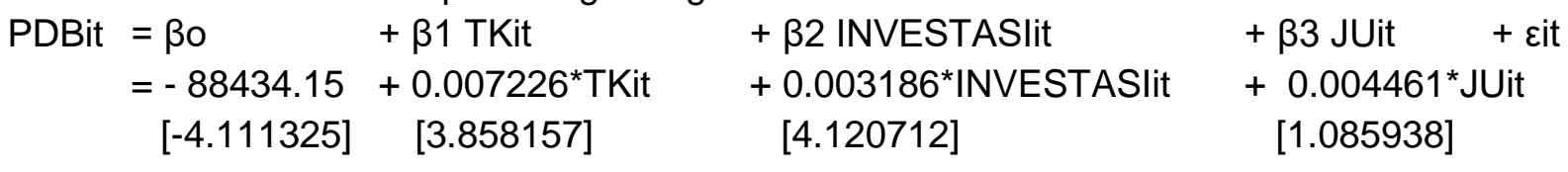

R2 $=0.964897 \quad$ F statistik $=197.9103$

\section{Pengujian Hipotesis}

1. Hasil Uji t

Tabel 5.

Hasil Uji t metode OLS pada tingkat signifikansi $95 \%$ dan $\mathrm{df}=38$

\begin{tabular}{llllll}
\hline Variabel Bebas & Koefisien & t-hitung & t-tabel & Probabilitas & Kesimpulan \\
\hline TK & 0.007226 & 3.858157 & 2.02439 & 0.0005 & Ho ditolak \\
INVESTASI & 0.003186 & 4.120712 & 2.02439 & 0.0002 & Ho ditolak
\end{tabular}


Sumber: Data Olah dengan Eviews 9

$\begin{array}{lll}1.085938 & 2.02439 & 0.2847\end{array}$

Ho diterima

Variabel tenaga kerja, berdasarkan hasil perhitungan uji-t, diperoleh t-hitung sebesar 3.858157 lebih besar dari nilai t-tabel 2.02439. Hal ini berarti menolak Ho sehingga variabel tenaga kerja berpengaruh dan signifikan terhadap pendapatan nasional (PDB).

Variabel investasi, memper-oleh hasil perhitungan uji-t sebesar 4.120712. Nilai ini lebih besar dibandingkan nilai t-tabel yaitu 2.02439. Hal ini berarti menolak Ho sehingga variabel investasi berpengaruh dan signifikan terhadap pendapatan nasional (PDB).

Hasil uji-t jumlah unit usaha diperoleh t-hitung sebesar 1.085938. Nilai ini lebih kecil dibandingkan nilai t-tabel yaitu 2.02439. Hal ini berarti menerima Ho sehingga variabel jumlah usaha tidak berpengaruh terhadap pendapatan nasional (PDB).

2. Hasil Uji F

Uji ini dilakukan untuk mengetahui apakah variabel bebas secara bersama- sama mempunyai pengaruh signifikan atau tidak signifikan terhadap variabel terikat. Pengujian ini menggunakan tingkat kepercayaan $95 \%$ dan df $1=3$, dan df $2=38$. Hasil uji $F$ diperoleh $F$ hitung sebesar 197.9103 lebih besar dari $F$ tabel (2.85) sehingga menolak Ho dan menerima Ha yang berarti bahwa secara statistik variabel bebas dalam penelitian ini secara bersama-sama berpengaruh signifikan terhadap variabel terikat yaitu pendapatan nasional (PDB).

3. Hasil Koefisiensi Determinasi $\left(R^{2}\right)$

Hasil estimasi diperoleh koefisien determinasi dengan nilai 0.964897 , itu berarti bahwa pendapatan nasional UMKM dapat dijelaskan oleh tenaga kerja, investasi, jumlah usaha, dan pendapatan nasional sebesar $96,5 \%$.

\section{Pengaruh Tenaga Kerja terhadap Pendapatan Nasional pada sektor UMKM di Indonesia}

Berdasarkan hasil estimasi tenaga kerja berpengaruh secara positif dan signifikan terhadap pendapatan nasional pada sektor UMKM di Indonesia. Tenaga kerja merupakan faktor penting dalam proses produksi. Pengaruh tenaga kerja yang positif terhadap pendapatan nasional sektor UMKM menunjukkan bahwa setiap peningkatan tenaga kerja sektor UMKM akan menyebabkan pendapatan nasional mengalami peningkatan. Sebagian besar UMKM masih bersifat padat karya, karena tenaga kerja dipandang sebagai faktor produksi yang dapat digunakan untuk meningkatkan daya guna faktor produksi lainnya seperti dalam pengelolaan usaha dan pemanfaatan modal. Peningkatan tenaga kerja berarti akan meningkatkan produksi usaha, sehingga akan menaikkan PDB.

\section{Pengaruh Investasi terhadap Pendapatan Nasional pada sektor UMKM di Indonesia}

Berdasarkan hasil regresi menggunakan metode regresi data panel, investasi berpengaruh dan signifikan terhadap pendapatan nasional pada sektor UMKM di Indonesia. Investasi merupakan salah satu faktor yang men-dukung dalam perkembangan UMKM. Investasi yang berpengaruh positif menunjukkan bahwa investasi akan meningkatkan PDB sektor UMKM.

Penambahan investasi dalam suatu usaha, akan meningkatkan produktifitas usaha tersebut dan PDB, hal ini sesuai dengan teori akselerasi, bahwa dalam jangka panjang, apabila pendapatan nasional bertambah tinggi, maka investasi akan bertambah tinggi pula.

Peningkatan investasi akan meningkatkan nilai tambah atau penghasilan untuk masa datang karena nilai tambah suatu investasi akan selalu mengalami peningkatan dari tahun ke tahun. Investasi yang ditanamkan pada sektor UKM dapat mendorong kenaikan output dan permintaan input sehingga ber-pengaruh terhadap kenaikan pen-dapatan dan perluasan kesempatan kerja yang selanjutnya dapat mendorong pertumbuhan ekonomi.

\section{Pengaruh Jumlah Unit terhadap Pendapatan Nasional pada sektor UMKM di Indonesia}

Berdasarkan hasil regresi dengan menggunakan metode regresi data panel, jumlah usaha tidak berpengaruh terhadap pendapatan nasional pada sektor UMKM di Indonesia. Jumlah unit merupakan salah satu faktor yang mampu meningkatkan penyerapan tenaga kerja. Dengan 
adanya penambahan jumlah usaha baru maka akan membutuhkan sejumlah tenaga kerja untuk melaksanakan usahanya tersebut, sehingga penambahan jumlah usaha baru akan menyerap tenaga kerja, dan meningkatkan output yang dihasilkan.

Dalam kasus ini, semakin banyak jumlah usaha yang bergerak di skala UMKM, berarti pemerintah akan semakin banyak memberikan subsidi kepada usaha - usaha tersebut, khususnya dalam hal subsidi bahan baku, bbm, dan listrik. Sedangkan usaha- usaha dalam skala UMKM tidak dipungut pajak oleh pemerintah sehingga penerimaan pemerintah tidak bertambah.

\section{Analisis Individual Effect}

Individual effect dilakukan untuk melihat kedinamisan perilaku individu seiring waktu.

1. Sektor perdagangan, hotel, dan restauran memiliki pengaruh individu terhadap PDB terbesar yaitu sebesar Rp.79.019,14 miliar. Hal ini terjadi dikarenakan sektor perdagangan, hotel, dan restauran secara tidak langsung dipengaruhi dengan perkem-bangan pariwisata di Indonesia yang saat ini terlihat cukup pesat perkembangannya dari tahun ke tahun. Hal ini memberikan dampak positif terhadap peningkatan fasilitas hotel dan restauran di Indonesia. Dengan adanya peningkatan fasilitas hotel dan restauran tersebut akan membuka lapangan kerja baru bagi warga Indonesia, meningkatkan kerjasama dengan investor dalam perkembangan hotel dan restauran.

2. Sektor jasa-jasa swasta yaitu sebesar Rp.19.025,81 miliar, hal ini dikarenakan adanya peningkatan jasa-jasa swasta diantaranya adalah produk yang dibutuhkan dan dihasilkan semakin komplek. Peningkatan kompleksitas kehidupan dapat memunculkan jenis jasa baru, peningkatan kualitas dan keterampilan sumber daya manusia dalam memanfaatkan teknologi yang mempermudah aksesbilitas menghasilkan jasa-jasa baru.

Jasa-jasa meliputi kegiatan pelayanan kepada masyarakat yang ditunjukkan untuk melayani kepentingan rumah tangga, badan usaha, pemerintah, dan lembaga-lembaga lain. Karakteristik usaha jasa secara garis besar dibagi menjadi dua, yaitu usaha jasa untuk memenuhi konsumsi dan usaha jasa untuk memenuhi kebutuhan usaha.

Usaha jasa untuk memenuhi kebutuhan konsumsi, seperti:
a. Usaha kuliner
b. Usaha pengiriman barang
c. Usaha transportasi
d. Usaha penyedia layanan internet dan telekomunikasi
Usaha jasa untuk memenuhi kebutuhan usaha lainnya adalah:
a. Jasa keuangan
b. Jasa penyedia karyawan outsource
c. Jasa layanan pengiriman barang
d. Jasa penyewaan peralatan atau kebutuhan kantor
e. Jasa pelatihan ke karyawan kantor

3. Sektor pertanian, perternakan, kehutanan, dan perikanan memiliki pengaruh individu terendah yaitu sebesar Rp.-98.044,95 miliar, rendahnya output sektor pertanian, perternakan, kehutanan, dan perikanan dikarenakan semakin berkurangnya lahan pertanian, perternakan, kehutanan, dan perikanan akibat terjadinya transformasi struktural dari sektor primer ke sektor sekunder

Transformasi struktural sendiri merupakan proses perubahan struktur perekonomian dari sektor pertanian ke sektor industri, perdagangan, dan jasa

\section{KESIMPULAN DAN SARAN}

Tenaga kerja UMKM, Investasi UMKM berpengaruh positif dan signifikan terhadap pendapatan nasional pada sektor UMKM di Indonesia. Jumlah unit UMKM tidak berpengaruh terhadap pendapatan nasional pada sektor UMKM di Indonesia.

Sektor perdagangan, hotel, dan restauran secara tidak langsung dipengaruhi dengan perkembang-an pariwisata di Indonesia yang saat ini terlihat cukup pesat perkembangan-nya 
dari tahun ke tahun. Hal ini memberikan dampak positif terhadap peningkatan fasilitas hotel dan restauran di Indonesia.

Sektor jasa-jasa swasta, adanya peningkatan jasa-jasa swasta diantaranya adala kompleksitas kehidupan dapat memunculkan jenis jasa baru, peningkatan kualitas dan keterampilan sumber daya manusia dalam memanfaatkan teknologi yang mempermudah aksesbilitas menghasilkan jasa-jasa baru.

Sektor pertanian, perternakan, kehutanan, dan perikanan memiliki pengaruh individu terendah, rendahnya output sektor pertanian, perternakan, kehutanan, dan perikanan dikarenakan semakin berkurangnya lahan pertanian, perternakan, kehutanan, dan perikanan akibat terjadinya transformasi struktural dari sektor primer ke sektor sekunder.

\section{DAFTAR PUSTAKA}

Fretes, P. N. De. (2007). Analisi tentang Pengaruh Investasi terhadap Pembangunan Ekonomi di Propinsi Papua. Jurnal Aplikasi Manajemen Volume 5 nomor 1

Gujarati, D. N., \& Porter, D. C. (2010). Dasar-dasar Ekonometrika. Jakarta: Salemba Empat Kementrian Koperasi dan UMKM. 2001-2013. PDB, Tenaga Kerja, Investasi, Ekspor, Jumlah Unit UMKM di Indonesia. Kemenkop dan UMKM. Jakarta

Kementrian Koperasi dan UMKM. Rencana Strategis Kementrian Koperasi dan

Lembaga Pengembangan Perbankan Indonesia. (2015). Profil Bisnis Usaha Mikro, Kecil, dan Menengah. Diakses dari http://www.bi.go.id/id/umkm/penelitian/nasional/kajian/Documents/Profil pada tanggal 17 Oktober 2016

Mankiw, N. G. (2013). Pengantar Ekonomi Makro. Jakarta : Salemba Empat. jakarta.

Nanga, Muana. (2001). Makro Ekonomi. Raja Grafindo, Jakarta.

UMKM Tahun 2015 - 2019. Diakses dari www.depkop.go.id pada tanggal 24 Oktober 2016

Widarjono, A. (2013). Ekonometrika Pengantar dan Aplikasinya. Yogyakarta: UPP STIM YKPN 